\author{
GERARD RONGE
}

\title{
"EAGLE? IT IS NOT HALF-TURTLE, HALF-THUNDER" THE PROBLEM OF ROMANTIC IRONY IN VADE-MECUM
}

The divergence of the theses proclaimed by Norwid, not only in Vade-mecum, leads some researchers to accuse the poet of lacking a stable, or at least clearly defined, worldview. ${ }^{1}$ Common sense suggests that such judgements are formulated primarily in order to provoke a kind of creative anxiety among Norwid Studies experts, "brought up" based on the studies on Norwid's work by Juliusz Wiktor Gomulicki and Zofia Stefanowska. Such works most often try to demonstrate that, what we are used to taking for granted in the area of literary studies can be challenged relatively easily through sufficiently skilful word play. This is supposed to stimulate researchers to constantly update their views and remind them of the need to verify them on a regular basis. The term "deconstruction" contained in the title of Wiesław Rzońca's work on Norwid additionally legitimises the assumption that these might have been the researcher's intentions. ${ }^{2}$ However, sticking to the "belief in interpretation," accusing Norwid of lacking his own worldview will eventually turn out to be a misconception.

It is true that it is not possible to create a short list that would clearly summarise Norwid's views. Indeed, it seems right to suspect that we are able reconstruct any of the poet's views on the basis of one of his poems, but we would soon find another work that would invalidate or at least significantly modify this view. The poet himself seems to warn the reader of this problem, as evidenced by the famous words from Ogólniki [Generalities]:

Ponad wszystkie wasze uroki -

Ty! poezjo, i ty, wymowo -

${ }^{1}$ Cf. K. Trybuśs comments on the book by W. Rzońca Norwid poeta pisma. Próba dekonstrukcji dzieła (K. TrYBuś, ,, Stary poeta.” Studia o Norwidzie, Poznań 2000, pp. 13-17).

${ }^{2}$ Ibid. 
Jeden wiecznie będzie wysoki:

$* * * * * * * * * * * * * * * * * *$

Odpowiednie dać rzeczy słowo! (Za wstęp (ogólniki) [As Introduction

(Generalities)], 9-13) ${ }^{3}$

Beyond, above all your charms,

You! poetry, and you, Speech! behold,

Ever the highest will be - this aim::

$* * * * * * * * * * * * * * * * * *$

To name each matter by its rightful - word! $!^{4}$

That is all Norwid promises his reader, no more no less. The motif of wandering, which the title of the collection connotes, is realised here as a wandering in search of that "rightful word." The views of this poet thus cannot be summarised - not because he did not have any, but the reasons should be sought elsewhere. They were either so complex that he himself was unable to express them and left behind only a testimony of his search for a means of expressing them, or he just managed to express them in the form of a hundred poems in the collection entitled Vade-mecum. In the latter case, these poems give a complete picture of his worldview, but only if read as a whole since any attempt at paraphrasing them would distort the picture. Finally, one more difficulty is encountered by those who would like to reconstruct Norwid's views on the basis of Vade-mecum - a downto-earth difficulty, but one that is nevertheless significant - as many as fourteen out of a hundred works in the collection have disappeared and another eight are known only in fragments. ${ }^{5}$

An attempt to apply deconstruction to Norwid's collection can certainly show that there are no such clearly formulated theses in any of the works that would not be immediately challenged or even discarded in another work. However, this "synthesis-less" dialectic also forces the reader to view Vade-mecum against the backdrop of the discussion on irony in $19^{\text {th }}$ century Europe.

The difficulty in tracing irony in Norwid's work lies mainly in the fact that his work can neither be adapted to Schlegel's model of Romantic irony, nor can it be described as an illustration of Hegel's criticism of that irony. It is also impossible to unequivocally state that the works included in Vade-mecum fit within the frame-

3 All the fragments of the lyrical works from among 100 works in the VM cycle are quoted after: C. NoRwID, Vade-mecum, compiled by J. Fert, Wrocław 1990. The Roman numerals indicate the ordinal number of a given work, the Arabic numerals indicate the quoted lines.

${ }^{4}$ C. Norwid, Poems, translated from the Polish by Danuta Borchardt in collaboration with Agata Brajerska-Mazur, New York 2011, p. 13.

5 C. NorwID, Vade-mecum, compiled by J. Fert, Wrocław 1990, p. XCVI. 
work of positive irony created by Kierkegaard. Norwid was probably not familiar with the Danish philosopher's works, but the surprising convergence of some of their views forces researchers today to juxtapose their works more and more often, and it is assumed that it is possible that the Polish poet had come across at least some of Kierkegaard's philosophical assumptions, particularly his views on irony. ${ }^{6}$ However, in order to decide what was Norwid's own attitude towards irony, it is essential to first trace in which places in Vade-mecum he approaches "infinite negativity" and in which places he approaches "finite positivity." This requires us to look at those distinctive features of Romantic irony, the elements of which can be found in Norwid's works.

First, we need to discuss Norwid's parabas is. The very title of the collection analysed here presents its author in some way. Norwid invites the reader to "follow him," offering himself as a guide during the journey undertaken in search of Truth or an excellent artistic form. In this way, he reveals himself as a conscious creator of a certain whole created for a specific purpose according to pre-established assumptions.

Włodzimierz Szturc defines "permanent parabasis" as a series of artistic tricks which serve to expose the fictionality of the world presented in a given work, which allows the introduction of the author's reality into the work, owing to which he can present his literary skills and creative power. ${ }^{7}$

The "permanent parabasis" in its purest form was implemented in a digressive poem. The defining feature of this genre is precisely the maintenance of a continuous dialogue between the creator and the receiver; the writer does not let the readers forget for a moment that he creates only a fictional work, often shares his creative dilemmas with the readers, coaxes them with false (ironic) modesty and apologises for the work's shortcomings. All of these mean to serve primarily as emphasis to his absolute power over the literary work and to remind the readers of the symbolic nature of the represented world. The artist also continues to take two opposing actions - he either seeks to diminish the meaning of the plot and the characters in front of the readers in order to convince them that these elements are merely a kind of pretext for discussion, or just a digression, or on the contrary he apologises to the readers that he allows the stream of words to flow and ensures that he is returning to the story. These treatments can sometimes serve to confuse the readers so they do not know what to focus on.

The description of Olga in Eugene Onegin seems to be a model example of Romantic irony used in its purest form:

${ }^{6}$ Cf. E. LuJewska, Norwid i Kierkegaard - czy spotkanie było możliwe?, „Poznańskie Studia Polonistyczne. Seria literacka" 18(2011), pp. 271-282.

7 W. Szturc, Ironia romantyczna. Pojęcie, granice i poetyka, Warszawa 1992, p. 167. 


\section{XXIII}

Obedient she had ever been

And modest, cheerful as the morn,

As a poetic life serene,

Sweet as the kiss of lovers sworn.

Her eyes were of cerulean blue,

Her locks were of a golden hue,

Her movements, voice and figure slight,

All about Olga — to a light

Romance of love I pray refer,

You'll find her portrait there, I vouch;

I formerly admired her much

But finally grew bored by her.

But with her elder sister I

Must now my stanzas occupy. ${ }^{8}$

It is impossible to find in Vade-mecum a "permanent parabasis," as outlined above, in such a model form. By no means is Norwid afraid to distance himself from his work, but this distance never consists in trivialising its meaning or the elements of its contents, and this never involves distancing himself from the ideas it expresses. The "permanent parabasis" is updated in the poet's work in the sense that Norwid makes art a tool in the hands of the artist-demiurge, and a tool for clarifying and expressing a certain philosophical position - the poet creates a "vademecum" that will lead the reader to specific ethical or poetic conclusions. This action falls within one of the aspects of the "permanent parabasis" mentioned by Szturc:

The "permanent parabasis," i.e. in essence, the author's constant leaning out of the created work, could also take on the form of a philosophical dispute initiated by the theme of the work or a fragment of it, or even a sharp polemic with opponents. Such a function of the parabasis resulted from its discursivity.

Norwid was therefore both eager to use irony understood as a rhetorical form of conducting a polemic, and to distance himself from his written work when it served to draw an additional line on the complicated map of his - already treated with all seriousness - philosophical and moral views. In the poem Krytyka [Criti-

8 A. Pushkin, Eugene Onegin, trans. H. Spalding, London 1881. Retrieved from: https://www. gutenberg.org/files/23997/23997-h/23997-h.htm [Accessed on 7 November 2020]

9 W. SzTuRC, Ironia romatyczna, p. 177. 
cism], the poet imagines possible reviews of his collection and satirically exposes the naivety and incompetence of his contemporary publicists:
$V M$ - złożone ze stu rzeczy drobnych -
Wyszło - - Kolega nasz (niespracowany
Krytyk) źle wróży z utworów podobnych!...
- Takowej wszakże dalecy odmiany,
W niespracowanym czasopiśmie naszym,
Zapowiedzianą przyszłością nie straszym.
(XCVIII, 1-6, poet's original emphasis)
$V M$ - composed of a hundred small things -
It came out - - Our friend (indefatigable
Critic) augurs ill for similar works!...
- Far from such a change,
In our unflagging journal,
We do not threaten with the announced future.

Above, one can see a parabasis functioning here in a similar way as in Pushkin's work, and yet devoid of the two features characteristic of the irony in Eugene Onegin. Firstly, the irony here does not take the form of a literal address to the reader, although the whole stanza is discursive in nature. Norwid used here a highly sublime form of silence, making the reader apparently "hear the unspoken," which he further reinforced with two consecutive pauses in the second verse. At least two full sentences resound in the first two verses of the work: "Imagine, reader, that Vade-mecum, which would be said to consist of a hundred small things, has already come out. Let us now consider what a critic could say about this work," even though these sentences were not uttered there at all - they were only "outlined," with those elements which are necessary to create a certain situation in the represented world of the work. The Romantic irony in this case consists precisely in that Norwid pretends to create some kind of fiction, and that he shows us a certain situation in the represented world (an anonymous critic writes a review of an existing work referred to as "VM"), but in reality he is talking to us about the work that we are holding in our hands. The double pause in the second verse can, in turn, be read as an "utterance" about this parabasis that is not articulated here, something similar to "I am not talking to you, but you know I am talking." The poet, by omitting the parabasis, is giving up this "imagine, reader" or "let us assume that," pretends that he wants us to believe in the reality of the represented world, and thus he gives up control over the work and grants this world autonomy. In this way, he gains control over the parabasis itself; instead 
of revealing his creative power through a direct statement, he reveals his power over the statement by abandoning it. The reader now receives a statement about the statement, a parabasis squared - all this due to the silence.

The second difference between the parabases in Onegin and Krytyka is that the irony in Krytyka is not aimed at the work itself, and the coquetry visible here ("small things") is not directed at the reader. By using seemingly indirect speech, the poet parodies not even the language of contemporary criticism but the characteristic way of reading texts - superficial, conceited and naive. There is no instantaneous negation of what has just been said which was so characteristic of Romantic irony. The poet, even though he plays a constant game with the readers, tries to confuse them, make them toil, and force them to light this candle mentioned in Ciemność [Darkness] - he always wants to remain honest with his audience. If the readers manage to break through the complicated poetics of Norwid's works, they can rest assured that they have learnt his position on some (always concrete) level. This does not mean that the poet has led the readers to any general Truth. Like no one else, he is aware that there are no ready recipes, and he will easily show that if a given assumption works in one situation, it may turn out to be completely useless in another. Norwid therefore does not treat distance as a manifestation of a sense of absolute freedom to negate, but rather as "an artistic means of reaching the truth or an expression of ontological complications," ${ }^{10}$ as Szturc describes one aspect of Romantic irony. It is for this reason that Vade-mecum may - to quote the words from the title work (I, 45-48) - be "ogryzmolone" [scribbled], the poet may be "omylon" [confused], but he is always "wielce rzeczywisty" [very real] towards the readers.

It seems that in order to properly understand this resignation of the author of Vade-mecum from the complete artistic freedom offered by Romantic irony, we should explain what Norwid's artistic ethic is.

Søren Kierkegaard defined the omnipotence of the ironist based on the freedom of absolute negation and the freedom of poetic creation:

Irony appears now on the stage as a character for whom there is nothing permanent, he gave up everything, and yet ha has full power and can do what he likes. If he lets something go on, he realises that he can annihilate it at any time, he knows it at the very same moment he lets something go on. If he postulates anything, he knows he has the right to cancel that, and he knows it at the very same moment he postulates it. He knows that he has the absolute power to bind and unbind. He has equal control over the idea and over the phenomenon, annihilating one with the other. He annihilates the phenomenon, because he knows that this does not correspond to the idea, he annihilates the idea, because he knows that this does not correspond to the phenomenon. And not without reason, since the idea and the phenomenon exist only in a

${ }^{10}$ Ibid., p. 93. 
mutual bond. But at the same time, irony wants to save its carefree life, because in the name of irony acts an individual subject - man. ${ }^{11}$

The implementation of irony in such a form is only possible after adopting an attitude of "absolute and infinite negation," which Kierkegaard mentioned in a previous part of his reflections. ${ }^{12}$ Irony understood in this way builds only through demolition and has the freedom to do so because it rejects the existence of what it destroys. And - as the Danish philosopher claims - it always destroys "in the name of something higher, which does not exist."13

We can now more clearly define the two poles of Romantic irony, between which Norwid tries to find the balance - on one hand, we have Schlegel's "infinite negativity," and on the other, Kierkegaard's "finite positivity."

Therefore, Norwid's hypotheses are so ambiguous not because he did not really have clear-cut views - he had a very clear worldview in the sense that he was not satisfied with most of the elements of the world around him. The fact is that he could not clearly indicate a positive alternative, but only stressed his adherence to the model of the "ironic subject" created by Kierkegaard:

For the ironic subject, the stagnant reality has already completely lost its legitimacy, its form seems imperfect to him and hinders his every move. On the other hand, he did not take possession of what is new. He only knows that the present does not correspond to the idea. He is the one who will put the present to trial. In a sense, the ironist is a prophet, constantly pointing to something that is coming, but he does not know what it is. ${ }^{14}$

On the face of this ignorance, the ironic subject may take two attitudes: the one proposed by Schlegel or that of Kierkegaard. In the former, the subject negates reality as such and can thus settle for destruction itself - liberated from the fetters of morality and ethics, he gains complete freedom to act, and he does not have to worry about the futility of his actions because he does not care about building anything. This attitude is somehow related to this Faustian power which "in wanting to do evil, constantly does good," or more generally, the whole mythology of "sad Satan." In fact, it is represented by many Romantic and post-Romantic literary heroes from Karl Moor to Ivan Karamazov and Dorian Gray. It seems that these statements, to a certain degree, foreshadowed what we would hear in a

11 S. KierkegaArd, O pojęciu ironii z nieustającym odniesieniem do Sokratesa, Polish trans. A. Djakowska, Warszawa 1999, pp. 268-269.

${ }^{12}$ Ibid., p. 255.

13 Ibid.

${ }^{14}$ Ibid., p. 254. 
few decades' time in Frederick Nietzsche's philosophy and the philosophical and aesthetic programmes of Modernism.

In contrast, the adoption of "Kierkegaard's" attitude requires the ironic subject to seek freedom in self-restraint. Here, instead of rejecting reality, the subject wants to acknowledge its existence and begins to govern it in order to reach a higher Truth which, for the time being, he is simply not able to determine. Szturc captures the difference between these attitudes in the following way:

For Kierkegaard, Romantic irony was a subjective lawlessness, which was guided by the conviction that it is possible to create the world and oneself as an unpunishable action, rejecting the possibility of establishing an ethic. The "infinite negativity" of Romantic irony was also supposed to be the boundary of Romanticism, which was born as a denial of a finite and objective vision of the world. Based on the foundations of pre-Romantic aesthetics, in the last part of his dissertation, Kierkegaard thus created a new concept of irony as "finite positivity" that does not deny reality, but starts to govern it. Its essence is the same as the phenomenon - it is the ability to constrain, to close everything that in human experience seems to be open, unlimited, immersed in the dialectic of creation.

One has to agree with Kierkegaard that his proposed attitude is strictly religious, because it irrationally (or better: anti-rationally) assumes the existence of some higher and absolute objectivity which should be sought, but which is itself inaccessible and unknowable.

The conflict between the two positions outlined above can easily be transferred onto the plane of today's philosophical disputes - it is almost analogous to the dispute between representatives of postmodern relativism and defenders of essentialism - and it can be pointed out here that the latter very often takes a religious perspective. This group includes Terry Eagleton, a British philosopher often referred to as a Christian socialist (by the way, it seems that after translating $19^{\text {th }}$ century political terms into today's language, exactly the same phrase could be used to describe both Norwid and Kierkegaard). It is worth looking at a fragment of his dissertation, After Theory, to see how he tries to face the same problems as Norwid using the tools of $21^{\text {st }}$ century philosophy:

However, not everyone agrees on what love or self-fulfilment is, which virtues are important, and generally accepts this whole model of good life. The virtues praised by Aristotle do not necessarily overlap with those which we, the modern people, would be inclined to affirm. They are entangled in the social history of his time, but his view of human nature, on the contrary, is generally insufficiently historical. Nevertheless, Karl Marx, a kind of crypto-Aristotelian philosopher, extracted convincing historical criticism from this ethic, just as his mentor

${ }^{15}$ W. SzTURC, Ironia romantyczna, pp. 96-97. 
Hegel had done before. It looks a bit like we are simply doomed to argue about the importance of self-fulfilment; and it is quite possible that the whole thing is too complicated for us to come to satisfactory conclusions. Contemporary existence, in its fragmentation, specialization and diversity, has proposed too many solutions to this issue to be ever easy to choose from. ${ }^{16}$

The search for the Truth begins with the basic assumption that two contradictory statements cannot be true at the same time. The "Kierkegaard's ironist" or today's essentialist will say that one of these statements must be wrong, even if it is not known which one; while the Romantic ironist will say that neither of these statements is true or wrong because there exists no Truth. The postmodern relativist may add that the truthfulness of both of these statements is possible, but it is strictly dependent upon the context in which they are made.

Norwid's distance to his work is thus different from the distance of Romantic irony in that the latter distances itself because it does not believe in the existence of any Truth, and what it creates is an arbitrary play for it. Norwid, on the other hand, treats this distance as a specific tool of cognition. He knows that the Truth is unknown to him for the time being so he checks his hypotheses in different situations, tests his convictions on different issues and tries to create a network of "concrete" truths, which seen as a whole, after distancing himself, will reveal a general and objective Truth.

In order to somehow illustrate the "working" of Norwid's irony, it is worthwhile to follow a few threads of this worldview network to recreate the poet's search for an "appropriate word" for a given issue, and to see how a certain kind of truth emerges from the constant negation in his works. It seems that the most representative works that are part of the Vade-mecum cycle will be those that refer directly to the idea because it is precisely the naive idealism that is being targeted by the most severe accusation of the poet within the whole Vade-mecum cycle.

The work Czemu nie w chórze [Why Not in a Choir] (XXVI) compares the act of inciting the society to an armed uprising which is doomed to end in a failure of Herod's massacre of the innocents. Norwid hates empty gestures. $\mathrm{He}$ always condemns "umieranie dla umierania" [dying for dying]. The poet is not susceptible to platitudes and is able to soberly judge a death that cannot change anything. It is a crime for him regardless of the circumstances surrounding it. Norwid "widział krew" [saw blood] (XXVI, 16), hence he will not stand in the choir singing "tryumfująca litania" [the triumphant litany] (XXVI, 15).

However, the first stanza of the poem Bohater [Hero] has a completely different message:

16 T. Eagleton, Koniec teorii [After Theory], Polish trans. B. Kuźniarz, Warszawa 2012, pp. 118-119. 
Czy już nie wróci czas siły-zupełnéj

Ani ma jeszcze zasłynąć

Wiek, gdy po runo ważono się płynąć

Ze złotej uwite wełny?... (LXXIV, 1-4)

Will the time of the absolute force not return

Nor is it yet to become famous

The age when they dared swim for the fleece

Woven of golden wool?...

The poet continues asking with regret: "Nie ma już więcej nic za powołanie / Nad strawność dobrą? byt zdrowy? -" [Is there nothing more for a vocation / Than good digestion? Health? -] (LXXIV, 15-16). Norwid was just as fiercely opposed to following clichés that were detached from reality, "to break into places where the worlds are zeros" (a paraphrase of the Verse 7 of the work Idee i prawda [Ideas and Truth]), as well as covering up a peculiar spiritual stagnation with a slogan of organic work which, in the poet's view, often boiled down to what we would call today petty burgeois. In the poem entitled Prac-czolo [Work in Brow's Sweat], the artist cautions that work must start with the brow, not with the hand or back. Behind every activity undertaken by a human being there must be an idea because without it the poet seems to speak to this "realny człek" [real human] (LXIII, 5), "Nic nie poradzisz!... każde twoje dzieło, / Choćby się z trudów herkulejskich wszczęło, / Niedopełnioném będzie i kalekiém..." [There is nothing you can do!... every single work of yours, / No matter how great Herculean hardships started it, / Will be incomplete, and crippled...] (LXIII, 6-8). By contrast, the poem Socjalizm [Socialism] is a warning against succumbing to beautifully sounding utopias. The poet reminds us that work on improving the world must be preceded by building a strong moral backbone: "- O! nie skończona jeszcze Dziejów praca, / Nie-przepalony jeszcze glob - Sumieniem!" [- Oh! the work of History is not finished yet, / The globe is not yet burned out - by Conscience!] (III, 11-12).

It is impossible to talk about Norwid's attitude to ideas without paying attention to the religious issues that occupy a special place in his work. It is probably on this plane that the poet's opposition to the worldview of realism can be most clearly seen. It should be pointed out, however, that this is not the trend presented by Balzac or Dickens, but rather the way the world is perceived by this social group, which in a few decades' time, would be called philisters by the representatives of Young Poland. In works such as Mistycyzm [Mysticism], the poet mocks the "zdroworozsądkowe" [common sense] attitudes of those people who would like to be described as "solidni" [solid]. The fact that many mystics turned out to be common madmen does not yet deny the existence of mysticism (XVII, 1-2). 
However, in Moralność [Morality], the poet mocks naive (or perhaps "idle") Catholicism by skilfully exploiting the fact that the Decalogue was written on two boards: "Jedna - władnie do dziś wszechsumieniem, / Druga - całym pękła kamieniem" [The one - till this day has ruled the all-conscience, / The other - broke with the whole stone] (LI, 6-7). The creator reproaches people who manage to worship only one God, not to misuse His name and to observe the holy day, but for whom the fulfilment of the other seven commandments which only apply to their neighbours turns out to be a task beyond their strength.

Norwid's attitude to Romantic irony is therefore as ambiguous as his attitude to other ideological, aesthetic and ethical-moral approaches which he reflects on in his works. It seems that irony for him is another tool the value of which depends solely on its usefulness in pursuing the higher goal - the discovery and expression of the Truth. At the same time, it means that Norwid radically rejects this pole of Romantic irony which lends itself the freedom of unfaithful destruction and consequently leads to philosophical nihilism. Above all, he needs the distance, made possible by the use of irony, to transcend the limitations and deficiencies of art as such - irony becomes necessary where the word cannot express what needs to be expressed. However, this does not mean that Norwid sees it as an instrument of power over the world of values, the objectivity of which (understood in a religious sense) cannot be challenged.

\section{REFERENCES}

DJAKOwSKa A., O stowach, które się ruszaja, [in:] S. KIERKEGAARD, O pojęciu ironii z nieustajacym odniesieniem do Sokratesa, trans. A. Djakowska, Warszawa 1999.

Eagleton T., Koniec teorii, trans. B. Kuźniarz, Warszawa 2012.

Fert J., Wstęp, [in:] C. Norwid, Vade-mecum, compiled by J. Fert, Wrocław 1990.

Gomulicki J.W., ,,Vade-mecum” jako Norwidowa summa poetycka, [in:] M. IngLOt, Cyprian Norwid, Warszawa 1991.

Inglot M., Arcydzieło Norwidowskiej liryki (rzecz o „,Vade-mecum”), [in:] IDEM, Cyprian Norwid, Warszawa 1991.

KierkegaArd S., O pojęciu ironii z nieustajacym odniesieniem do Sokratesa, trans. A. Djakowska, Warszawa 1999.

KLEINER J., Zarys dziejów literatury polskiej. Od poczatków do 1918 r. revised and supplemented by S. Kawyn, J. Spytkowski, T. Ulewicz, Wrocław 1968.

Lijewska E., Norwid i Kierkegaard - czy spotkanie było możliwe?, „Poznańskie Studia Polonistyczne. Seria literacka" 18(2011), pp. 271-282.

Miтоseк Z., Teorie badań literackich, Warszawa 2005.

Norwid C., Vade-mecum, compiled by J. Fert, Wrocław 1990. 
Pushkin A., Eugene Onegin, trans. H. Spalding, London 1881. Retrieved from: https://www.gutenberg.org/files/23997/23997-h/23997-h.htm [Accessed on 7 November 2020].

RzoŃCA W., Norwid - największy poeta drugiej połowy XIX w., „Przegląd Humanistyczny” 6(2007), pp. 35-43.

Szturc W., Ironia romantyczna. Pojęcie, granice i poetyka, Warszawa 1992.

Trojanowiczowa Z., Ostatni spór romantyczny. Cyprian Norwid - Julian Klaczko, Warszawa 1981.

Trybuś K., ,, Stary poeta. ” Studia o Norwidzie, Poznań 2000.

Trybuś K., Pamięć romantyzmu. Studia nie tylko z przeszłości, Poznań 2011.

Witkowska A., Wielcy romantycy polscy. Sylwetki. Mickiewicz, Stowacki, Krasiński, Norwid, Warszawa 1980.

Wyka K., Norwid nieobecny, [in:] IDEM, Cyprian Norwid. Studia, artykuty, recenzje, Kraków 1989.

Wyкa K., Pochwała niejasności Norwida, ibid.

\title{
"EAGLE? IT IS NOT HALF-TURTLE, HALF-THUNDER." THE PROBLEM OF ROMANTIC IRONY IN VADE-MECUM
}

\author{
S u m m a r y
}

Numerous studies on the works composing the volume Vade-mecum confirm that although the individual poems are characterised by great ethical sensitivity and strong moral rigour, it is difficult to clearly define the worldview of Norwid's work. The author of the article proposes an interpretation of Vade-mecum, taking into account the problem of Romantic irony. The poet uses irony as a tool to reach the elusive Truth. For him, ironic distance is not distancing himself from the views professed in particular works, but an awareness of the imperfections of a language which may falsify those views. Irony helps him in his quest to "name each matter by its rightful - word," not allowing the language to simplify or reduce the moral statements expressed in individual works.

Key words: Cyprian Norwid; Søren Kierkegaard; Romantic irony; Vade-mecum; permanent parabasis.

Translated by Rafat Augustyn

Gerard Ronge - PhD student at the Institute of Polish Philology of Adam Mickiewicz University in Poznań. Principal investigator in the project "The category of novelty in Polish contemporary literature. Originality after postmodernism" implemented in the framework of the Ministerial Programme "Diamond Grant." He is interested in literary theory and philosophy; e-mail: gerard.ronge@gmail.com. 